\title{
Sir Anthony Denny: A Tudor Servant in Office*
}

NARASINGHA PROSAD SIL

Sir Anthony Denny had an unusually uneventful career in the turbulent reign of Henry VIII. His life, humdrum and honest, remained unaffected by the habitual excitement and turmoil of court politics. Until recently he has thus been generally dismissed as an inconsequential figure. ${ }^{1}$ One scholar even stated that Denny was not much of anything at all, except a lifelong friend of King Henry. According to her, "it is difficult to understand" why "Henry, good judge of character and admirer of ability," chose this "least able man" as a servant. ${ }^{2}$ This statement is of course demonstrably false. Denny simply was not, like his Elizabethan counterpart Christopher Hatton, "a mere vegetable of the court that sprang up at night and sank again at his noon." ${ }^{3}$ A servant of the King, he was also an officer of the kingdom. His activities at the Henrician court, especially in the King's privy chamber, illuminate the operations of the royal household on the one hand and the nexus between the king's servant and the state servant on the other. His intimacy with the King as a gentleman of his privy chamber gave him an importance at court equal to that of a privy councillor, even though he did not sit in the Henrician council. ${ }^{4}$ Denny's career thus reveals the importance of service in the king's household, the seat of Tudor government and administration. Most important, his life illustrates that rare quality of a courtier-his almost ubiquitous popularity - in a world that was factious, conspiratorial, unprincipled, and uncharitable.

$$
* * *
$$

Anthony Denny was probably born into the ancient Denny family of Chesterton, Huntingdonshire, a branch of which later settled in Hertfordshire. ${ }^{5}$ His grandfather William had been a sheriff of Hertfordshire, and his father Edmund had been Henry VII's remembrancer during 150409 and later worked as a clerk and subsequently as a baron of the exchequer under Henry VIII. The Dennys were a family of royal servants. Even their

* An earlier version of this paper was presented at the Seminar of the Department of History, University of Benin, on 28 January 1981 . I thank those who made some useful comments on it and, in particular, Professor Philip A. Igbafe, who chaired the session. 
matrimonial relationships revealed close connection with the government. The widow of Thomas Denny, Anthony's elder brother, remarried Robert Dacres of Cheshunt, master of Requests and, during 1542-44, a privy councillor. Anthony's sister Joyce first married William Walshingham and was mother to Francis, Queen Elizabeth's secretary of state. She remarried Sir John Cary, a cousin of Henry VII's. Another sister, Mary, married Sir John Gates, Anthony's colleague in the privy chamber. The youngest sister, Martha, married Sir Wymond Carew, treasurer of the Court of First Fruits and Tenths during 1545-49.

Information on Denny's early life and education is far from adequate. Whatever little evidence there is of his educational background points to his humanistic upbringing at St. Paul's school and later at St. John's college, Cambridge. Contemporaries regarded him a patron of learning and respected him for his faith in restituenda vera religione. ${ }^{6}$ Nicholas Wentworth believed that he was "a sure friend of truth and a faithful setter forward thereof." As a royal servant he always supported the King's Reformation. ${ }^{8} \mathrm{He}$ was in fact a friend of the reforming archbishop Thomas Cranmer. ${ }^{9}$ His wife Joan belonged to the court of Queen Catherine Parr, Henry VIII's sixth and last wife. Lady Denny even appears to have been acquainted with that controversial female firebrand Anne Askew, whose determined violation of the sacrament had led to her arrest, torture, and eventual death at the hands of such powerful conservatives at court as Bishop Stephen Gardiner, Thomas Wriothesley, and Richard Rich. ${ }^{10}$

Yet Denny's zeal for the new religion never conflicted with his loyalty to Henry. He never antagonized the King by assuming any extreme Protestant posture. If he sympathized with or subscribed to the reformed faith, as a loyal government servant he also took notice of heretical books. ${ }^{11}$ His religious views were moderate, though not as conservative as those of the King. Possibly because of his moderate religious position he was selected by the King as one of the councillors in charge of Edward VI's government during his minority. ${ }^{12}$ A careerist lay courtier, Denny did not have any extreme and inflexible religious conviction. His attitude to religion might well have echoed that of Roger Edgeworth, who reminded everyone "that although divinity be a science very profitable for the soul health, yet small gains to the purse, or to the world ariseth by it."13

Denny certainly was a patron of learning who had saved a school and a library from dissolution. ${ }^{14} \mathrm{He}$ also appears to have had a personal penchant for academic life as we learn from his conversation with the famous Tudor educator Roger Ascham, a close friend of his. Denny is reported to have remarked to his friend that "if two dewties did not comaund him to serve, th' on his prince, th'other his wiffe, he wold surelie becum a student in S. Johns ...."15 Such fondness for learning was, however, a quite commonplace attitude among many educated men in the sixteenth century. 
Denny certainly was not, as in Ascham's friendly hyperbole, a zealous "Maecenas of learned men," who had little time for anything beyond "religion, doctrina, respublica."16

\section{$* * *$}

We learn a good deal about Denny's activities in the Henrician court from the mass of state papers calendared as Letters and Papers of Henry $V I I I$. But his early contact with court is difficult to trace precisely. There is simply no direct evidence of his first employment, although, from a contemporary secondary source, we can infer that he began his career under a senior courtier, Sir Francis Bryan, in diplomatic missions abroad. ${ }^{17}$ A native of Herefordshire, Bryan was the King's favourite in the early years of the reign, and had accompanied Henry on various missions to Europe since the days of the Field of the Cloth of Gold. In 1528 Bryan was at the French court carrying Henry's letter to the mother of King Francis I. ${ }^{18}$ Perhaps Denny's experience in Bryan's service brought him to the King's attention. In his eulogy written on the occasion of Denny's death, Sir John Leland wrote, "That wisest king observed this/And as your patron took you into his service." 19 Most probably he was employed in Henry's court in the late 1520s. Sometime after 1525 he received a list of heretical books from John Newdigate, a gentleman of the privy chamber. Denny must have been important enough at this time to be entrusted with intelligence concerning heresy. ${ }^{20}$ Even so, as late as 1531 , he perhaps continued to act as Bryan's servant. ${ }^{21}$ It is highly unlikely, as Professor Richardson has claimed, that by 1528 Denny had already become a gentleman of the privy chamber and the keeper of the privy purse. We do know that as late as 9 September 1536 he remained a groom of the chamber, a post of lower rank. ${ }^{22}$

In the 1530 s Denny held four posts in the King's household. He was yeoman of the wardrobe of robes, keeper of the royal palace at Westminster, groom, and later, gentleman, of the privy chamber, and keeper of the privy purse. The appointment at the wardrobe perhaps began in 1535 and it appears to be the earliest. ${ }^{23}$ In the wardrobe Denny was in charge of the royal jewelry and robes, and he purchased various materials such as Holland cloth, silk, quilts, and blankets. He also seems to have organized this department with such routine procedures as registering orders, deliveries, and payments. As a yeoman of the robes he received an annual wage of $28 \mathrm{~s} .^{24}$

His connection with the privy chamber can be traced as early as $1533 .{ }^{25}$ He can be identified as "of the privy chamber" on an indenture dated 28 May $1536 .{ }^{26}$ On 9 September of that year he received a grant as groom of the privy chamber. ${ }^{27} \mathrm{He}$ was first mentioned as a gentleman of the privy chamber in a list of household officials about the beginning of $1539 .{ }^{28}$ As a 
gentleman he acted as a liaison officer between the monarch and the courtiers and subjects at large. The Letters and Papers contain innumerable suits addressed to him directly, or through his junior colleague and brotherin-law John Gates, which describe his activities in the privy chamber. These range from maintaining the King's clocks, looking after his books, receiving suits for various favours such as employment in the royal household to matters touching local administration, affairs of the Marches of Calais, of the Scottish nobles, and, finally, intelligence. As a gentleman, too, he was empowered to convey the King's commands or commendations to other royal servants. ${ }^{29} \mathrm{He}$ also usually carried important missives to and from the King. ${ }^{30}$ Denny appears to have assumed some of the responsibilities of his former patron Bryan. In his letter of 26 January 1539, the French ambassador reported on his dealings with Denny in place of Bryan, who had hitherto been negotiating with the French for the sailcloths seized at Brittany. ${ }^{31}$ By 1546 Denny had become one of the two chief gentlemen of the privy chamber. It is not very clear if the chief gentlemanship was a promotion for him from the standpoint of responsibility or remuneration. Nevertheless, the change in designation does suggest some sort of career advancement. ${ }^{32}$

Though Denny had no formal appointment in the privy purse (the appointment was made orally), he appears to have been entrusted with it even as a modest servant in the royal household. In 1536 and in 1537, both Stephen Vaughan and Brian Tuke had large financial dealings with Denny. ${ }^{33}$ The chief repository of the King's private fund was Westminster Palace. Keepers or custodians of this palace were also keepers of the privy purse. The keepership of the privy purse was an informal appointment for a trusted servant who received it in conjunction with his formal assignment in the royal chamber. Under Henry VII the treasurer of the chamber and the keeper of the royal jewels had both acted as special custodians of the royal purse. When Henry VIII began to withdraw money from the public treasuries and demanded a definite reserve at his ready disposal, he chose his financial managers from among his friends and confidants in the privy chamber. Thus William Compton had informally but unmistakably assumed charge of the privy purse. ${ }^{34}$ Similarly, Denny, who undoubtedly qualified on the criteria of familiarity and faithfulness, came to manage the King's private money as a successor to Compton. In fact, he had been working as the keeper of Westminster Palace for at least two years before his formal appointment at Westminster on 20 September $1538 .{ }^{35}$ By 1542 he was clearly in charge of the privy purse. Though the keepership of the palace was a responsible assignment, it fetched a modest wage of $6 \mathrm{~d}$. a day. As the job involved safe keeping of the king's valuables, the officer in charge had to obtain discharge or clearance from the commissioners specially appointed to examine the keeper's accounts. ${ }^{36}$ 


\section{4 / Renaissance and Reformation}

As the keeper of the privy purse Denny handled substantial amounts of money. From 1536 right up to the end of 1546 he deposited more than $£ 81,000$ to the King's coffer. During roughly the same period he disbursed more than $£ 58,000$ for the King's war against Scotland and on the King's works at Westminster. ${ }^{37}$ Actually, the total volume of receipt and expenditure by Denny is even larger. During the last five years of Henry's reign he received a total of $£ 243,387$ s. $63 / 4 \mathrm{~d}$. which he spent according to the King's oral orders. ${ }^{38} \mathrm{~A}$ conscientious manager of royal money, Denny strove to control grafts and false payments. He thus collaborated with David Marten, a zealous comptroller of the King's works, in supervising the accounts of James Nedeham, a greedy surveyor of the King's works suspected of making underhand payments to himself. ${ }^{39}$ Sir Robert Southwell, Master of the Rolls, and Sir Edward North, Chancellor of Augmentations, were commissioned to oversee the accounts of Sir John Gresham, who had received a large sum from Denny. ${ }^{40}$

Like many other royal favourites Denny was also granted several sinecures such as the collectorship of tunnage and poundage of the port of London. ${ }^{41} \mathrm{He}$ had several appointments as steward, bailiff, and keeper of manors and parks. The emoluments for all these positions, including his salary as a gentleman of the privy chamber, were indeed substantial. His minimum income from office prior to death amounted to about $£ 200$ per annum. Admittedly, some of his appointments brought occasional rewards, but either their amount was modest or they were granted infrequently. On occasion he would not even receive his regular salary for one of the posts. ${ }^{42}$ On the other hand, he chose expensive gifts for the King. For example, he had the famous Dutch artist Hans Holbein design a clock as a New Year's gift for the King. ${ }^{43}$ Though salaries were modest, profits from royal service were much more attractive. One easily forms a fair idea of these profits and perquisites when one looks into the patent rolls of Henry's reign describing and registering innumerable grants to Sir Anthony.

Denny's activities in the royal household defy precise definition. His financial and various other chores in the privy chamber make him at once a personal servant of the King and an officer of the state. Perhaps this confusion reflected the very nature of the early Tudor government. In spite of the administrative reforms of the 1530 s, so well analyzed by Professor G.R. Elton and so emphatically hailed by him as "revolutionary," Henry VIII's government remained essentially personal, in which flexibility rather than definition was the rule and in which the needs of the state were often indistinguishable from those of the monarch. Those who catered to his needs also served the state. The King's men had become statesmen and vice versa. Most probably such flexibility did not hamper the increasing professionalization of Tudor government. After all, one could cite many topranking bureaucrats in the American government today who also happen 
to be close personally to the president. ${ }^{44} \mathrm{~A}$ royal servant as well as a state servant, Denny seems to have trained himself on the job. He served as nobody's apprentice. He appears to have inherited his family's natural flair for administration.

$$
* * *
$$

During the 1540s Denny came closer to his monarch. He was one of the first few intimate servants whom Henry took into his confidence while lamenting his initial contact with his continental wife Anne of Cleves. ${ }^{45}$ As John Strype reports, the King confided to Denny "how indede his Highnes could not induce hymself to have affection to the Quene," who, to the utter dismay of her outraged husband, possessed a man's chest and not a woman's breast! And Denny appropriately calmed his master down by lamenting the strange fate of princes, who, in matters of marriage, did not have that personal choice which even the poorest man in society could claim as his prerogative. ${ }^{46}$ The nearer Denny came to the King the more influential he grew in service. From 1543 his responsibilities in the privy chamber widened. He was now seen receiving information on the defense of Calais, on the French preparations for war, and on continental situations in general ${ }^{47} \mathrm{He}$ accompanied the King to Boulogne in 1544 where, on 30 September, after the city had capitulated to the English, he was knighted. ${ }^{48}$ From 1544 his influence in the privy chamber was superior to that of his senior colleague Thomas Heneage. On 20 September 1545, along with Gates and William Clerc, he was authorized by the King to put the royal stamp on all documents emanating from the monarch, whose growing illness and infirmities occasioned this arrangement. ${ }^{49}$ The years after 1540 were Henry's, as far as the day-to-day administration of the realm was concerned. The once ubiquitous and most powerful servant Thomas Cromwell was gone. The aging but administratively more mature monarch now presided over the administration assisted by his intimate servants, of whom Denny certainly was one of the most prominent.

Denny's increasing influence in government was recognized by several powerful and ambitious politicians and royal servants such as Sir William Paget, Sir William Petre, and above all, the rising star of the council, the Earl of Hertford. ${ }^{50}$ One of the most revealing instances of Denny's intimacy with the King is to be seen in the depositions made by him and William Herbert after Henry's death that the king "would always when Mr. Secretary [Paget] was gone tell us what passed between them." 51 When a veteran councillor like Sir Thomas Cheyney had broken his son's engagement with Denny's niece after it had been engrossed, he was rightly reprimanded by a correspondent that Denny was a man "near about the King and one unmeet to be trifled or mocked with." 52

Henry VIII's administrators earned distinction not by virtue of their 


\section{6 / Renaissance and Reformation}

office only, but perhaps more appropriately, by their ability to elicit their master's confidence and trust. James Hooker commented some two decades ago, "So much depended upon personality and proximity to the throne, that it is impossible to separate performer from performance." ${ }^{33}$ More recently, Dr. Robert Braddock has reemphasized that in Tudor administration "the relative importance of an office depended upon the man who held it." 54 Thus, though an affable and honest man, Denny was influential by virtue of his personal access to the monarch. As early as the thirteenth century, the author of the legal treatise Fleta had rightly noted that whoever was nearer the king was the worthier: "in hospitio pro regula habetur, quod propinqiuor sit quis Regi, tanto dignior."55

Denny carefully avoided the court factionalism of the last years of Henry's reign. He managed to maintain neutrality enlisting neither with the faction of Gardiner and the Duke of Norfolk nor with that of the Earl of Hertford and John Dudley. Two deaths in 1546 might have caused his uneasiness: the deaths of Anne Askew and Henry Howard, the impetuous Earl of Surrey. One was burnt for her declared heresy, while the other was beheaded for blazoning the arms of Edward the Confessor, which obviously was an act of treason. Denny's wife had shown her sympathy for Anne (at least that was what her persecutors wanted to believe), while Surrey was Denny's admirer. ${ }^{56}$ Denny did not suffer on their account even in those "perilous times." He scrupulously avoided any extreme religious or political group and gave his loyalty to none other than the King. His fearless intimacy with his master and the latter's respect and love for his faithful servant are illuminated by that famous episode recorded by John Fox. During the last hours of the King's life nobody dared to approach the royal patient to remind him of his impending death, because it was against the law to forecast the king's death. Yet, as Fox tells us, "Master Denny, who was specially attendant upon him boldy coming to the king, told him what case he was in, to man's judgment not like to live; and therefore exhorted him to prepare himself to death, calling himself to remembrance of his former life, and to call upon God in Christ betimes for grace and mercy, as becometh every good christian man to do."57 The dying king appeared to accept this exhortation with composure. He had made Denny an executor of his will and a privy councillor to his heir. Denny also received a substantial bequest, greater than that of a number of courtiers and councillors politically and socially superior to him. ${ }^{58} \mathrm{His}$ intimacy with his late monarch was further recognized during Henry's funeral procession. While all other notables rode on either side of the chariot bearing the royal corpse, "then were set at the head and feet of the said corpse Sir Anthony Denny and Sir William Herbert, two of the chief of his privy chamber." 59 In the weeks following, Denny's position was patently clear even to outside observers. When, on 10 February 1547, the Imperial ambassador report- 
ed on the newly formed council in England, he was convinced that Denny was "the most confidential of any of the gentlemen of the chamber." 60 The ambassador's conviction was well founded. Four months later, a royal patent recognized Denny "the most intimate of Henry VIII's council and chamber." 61

During Edward VI's reign Denny became a privy councillor, though he continued to work in the royal household. He was one of the nine councillors appointed by the Duke of Somerset to remain with the King in London during the Scottish campaign of 1547 . In that year he also became a commissioner of the peace for Essex and Hertfordshire. ${ }^{62}$ In the same year, too, he was elected to the House of Commons. ${ }^{63}$ During most of 1547 he was also busy managing the household of Edward and taking care of Westminster Palace ${ }^{64}$ In fact, he obtained a formal appointment as a gentleman of Edward's privy chamber on 24 December $1547 .{ }^{65}$ As a councillor he was not very active. There are extant a few letters among the proceedings of the privy council on which Denny's signature appears. ${ }^{66}$ His only serious business as a privy councillor was his participation in the trial and execution of Lord Seymour of Sudeley, admiral of England, and Protector Somerset's younger brother. ${ }^{67}$ Denny, however, did not live long. He died in office in 1549, not quite old yet, but a respectable and respected servant of the crown.

$$
\text { *** }
$$

Denny advanced in his career slowly but steadily. The key to his success lay in his personal qualities like moderation and loyalty, as well as his ability to influence the King. His admirer Sir John Cheke referred to him as a man who "was able to mould Henry's mind, now mixing the useful with the sweet, now weaving the serious things with the light ones, great with small." ${ }^{88}$ Sir Anthony had seen the vicissitudes of fortune of powerful men at court and council, and had learnt the real nature of politics in the Tudor court. His remark to Ascham made some time in 1548 adequately reflected his insight:"'The Corte ... is a place so slipperie, where ye shall many tymes repe most unkyndnesse where ye have sown greatest pleasurs, and those also readye to do yow moch hurt, to whom you never intended to think any harme." 69 It is, however, comforting to note that the author of this remark escaped the usual misfortune and squalor of curial politics, for there is no evidence of any personal enmity against him. Certainly he was not treated merely as a senior but otherwise inconsequential royal factotum. As noted earlier, powerful politicians recognized his influence and importance at court.

Admittedly there is nothing very unusual about Denny's advancement in his career. Indeed there were many others who became powerful and prominent in Henrician administration and augmented their position 


\section{8 / Renaissance and Reformation}

through the next reign and beyond. What is worth considering, and is truly surprising about Anthony Denny is the fact that, unlike many others who owed their halcyon days to the continual patronage of powerful men at court, he was able to attain his fortune and maintain his popularity without the intervention of any influential politician. This is all the more surprising in an age which put a high premium on "mediation and remembrance of noble things" rather than on "sufficiency and merit" for the advancement of a courtier's career. "To receive favors of princes," remarked Federico, a character in Castiglione's Book of the Courtier, "there is no better way than to deserve them."'70 Denny's fortune would surely have elicited Messer Federico's unqualified approbation..$^{71}$ Compton, his predecessor in the privy purse, was accused by his biographer as one who had "studied the king's nature rather than advised him."72 Denny's biographer, on the other hand, will certainly recognize that Sir Anthony sailed successfully in the hazardous and uncertain "court seas" not because he just happened to be lucky, but because, above all, he was that ideal courtier, who could "so use his Master's favour ut ne[que] ei unquam molestus esset, ne[que] invidiae aliorum obnoxius." 73

University of Benin, Nigeria

\section{Notes}

1 Except for a few purely biographical genealogical works, the only serious work on Denny's role in national administration remains David R. Starkey, "The King's Privy Chamber, 1485-1547" (unpublished $\mathrm{Ph}$.D. thesis, Cambridge University, 1973). Professor Geoffrey R. Elton has rightly called Denny a "useful and influential man." Reform and Reformation: England, 1509-1558 (Cambridge, Mass., 1977), p. 337.

2 Jane Schwartz, "Practisers in Princes' Causes: Tudor Privy Councillors from 1540 to 1558 " (unpublished Ph.D. thesis, Yale University, 1951), pp. 43-45.

3 Sir Robert Naunton, Fragmenta Regalia (London, 1641), "Hatton."

4 The epitaph of Charles Denny refers to his grandfather Sir Anthony as a "Privy Councillor to King Henry 8." Robert Clutterbuck, The History and Antiquities of the County of Hertford (3 vols., London, 1815-27), III, 256. The royal patent of June 1547 described Denny as "the most intimate of Henry VIII's council and chamber." Calendar of Patent Rolls. Edward VI (6 vols., London, 1924-9, I, 243 (hereafter CPREd). My italics.

5 For information on Denny's genealogy, see Herbert L.L. Denny, "Biography of the Right Honourable Sir Anthony Denny, P.C., M.P.," Transactions of East Hertfordshire Archaeological Society, III (1906); "Pedigrees of Some East Anglian Dennys," The Genealogist, 38 (1922); "Some Pedigrees of Denny, Le Denneys, etc.," Proceedings of Suffolk Institute of Archaeology and Natural History, XIX, 2 (1926). Conflicting genealogical information about the Dennys may be seen in Notes \& Queries, 8th ser., IV (1893), 294.

6 The Whole Works of Roger Ascham, ed. Rev. Dr. Giles, 3 vols. (London, 1865), I.i.65,73: Ascham's letters to Denny, November 1545 \& 8 November 1547.

7 Letters and Papers, Foreign and Domestic, of the Reign of Henry VIII, eds. John S. Brewer et al, 21 vols. with Addenda, (London, 1862-1932), XIX.i.19 (hereafter LP).

8 John Foxe, Actes and Monuments (London, 1563), Sig. PP5fi.

9 The Acts and Monuments of John Fox, ed. Stephen Catley (8 vols. New ed., London, 1838), V, 562 (hereafter Acts and Monuments).

10 Ibid., p. 542. For Anne Askew, see Select Works of John Bale, ed. Henry Christmas (Cambridge, 1849), pp. 220-42; Derek Wilson, A Tudor Tapestry (Pittsburgh, 1972), pp. 180-241. Anne 
told her tormentors that she had received $8 \mathrm{~s}$. from a man who claimed to have been sent by Lady Denny. Joan Denny's help to the condemned radical is thus uncertain. On the other hand, she appears to have received money as one of the "religious women" of Sion monastery, Middlesex, from its receiver John Mores ( $L P, \mathrm{XV} .840)$. This somewhat puzzling reference to her as a religious woman does create a problem as to Lady Denny's religious inclination.

11 LP, I. Addenda.i.752.

12 James A. Froude, The Reign of Henry the Eighth, 3 vols. (London, n.d.), III, 421 and n. 1; Alfred F. Pollard, England under Protector Somerset (London, 1900), p. 21; Gustav Constant, The Reformation in England, 2 vols. (New York, 1942), II, 22.

13 The English Sermon, com. Martin S. Smith, 3 vols. (Cheshire, 1976), I, 10-11.

14 Correspondence of Matthew Parker, eds. John Bruce \& Thomason Perowne (Cambridge, 1853), p. $33 \mathrm{n}$.: Denny's letter to the commissioners for the dissolution of Stoke college, 29 February 1547; Denny, "Biography of Anthony Denny," p. 202.

15 Original Letters of Eminent Literary Men of the Sixteenth, Seventeenth and Eighteenth Centuries, ed. Henry Ellis (London, 1843), p. 14: Ascham's letter to William Cecil, 23 March 1553.

16 Works of Ascham, I.i.73: Ascham's letter to Denny, 8 November 1547.

17 John Leland, Principium ac Illustrium Aliquot \& Eruditorum etc. (London, 1589), p. 151: “Tum desiderio captus peregrina vivendi/Acceleras votum, duxque Briennus erat" ("Then desirous to see foreign lands,/You hastened to fulfill your promise, and Bryan was your master").

18 LP, III.i.3583; IV.ii.4656.2.

19 Principium ac Illustrium, p. 151: "Senserat hoc regum qui prudentissimus/Unus te famulum fautor constituitque suum."

20 See $n .11$ above.

21 LP, V.363: on 16 June 1531 Denny carried a letter from Bryan and Dr. Edward Cox to Henry.

22 Walter C. Richardson, Tudor Chamber Administration, 1485-1547 (Baton Rouge, 1952), p. 93; History of the Court of Augmentations 1536-1554 (Baton Rouge, 1961), p. 352.

23 LP, IX.85, 218; X.912, 1132; XIII.i.309.

24 LP, I.Addenda.ii.1724; XIII.ii.1201, 1280 (fo. 4).

25 Historical Manuscripts Commission (hereafter HMC). Seymour Papers 1532-1686 (London, $1968)$, p. 2. His precise status at this time is not known.

26 LP, XII.i. 571.

27 LP, XI.519 (12).

28 LP, XIV.i.2. Twenty-nine persons appeared on this list of 1539.

29 LP, I.Addenda.ii.1869; XVIII.ii.211 (pp. 109-10); XIV.i.1120, 1145; ii.284; XVIII.Appendix.11; XIX.i.23; I.Addenda.ii.1593, 1799; XX.i.769; XVIII.i.911; XVII.526; XVIII.i.71, 957; XIV.ii.207.

30 State Papers Published under the Authority of His Majesty's Commission 11 vols. (London, 1830-52), I, 618 (129) (hereafter SP).

$31 L P, X I V .144$ (p. 53).

$32 L P, X X I . i i .648 .60$. Dr. Starkey attaches great significance to Denny's position as the chief gentleman who also became a groom of the stole on 30 April 1547. Unfortunately Starkey's energetic effort to demonstrate the primacy of the groom of the stole through intelligent inferences does not really make his point "fairly decisive," as he claims, when, on his own admission, the evidence is "thin"-which it is. "King's Privy Chamber," pp. 243, 263. Most of his stronger arguments are based on the well-known developments of the groom's position in the seventeenth and eighteenth centuries.

33 LP, X.376; XIII.i.309.

34 Richardson, Chamber Administration, pp. 92-3; Court of Augmentations, pp. 351-2.

35 LP, XII.ii. 796 (xiii); XIII.ii.491 (11). On 30 September 1536 he had been presented with a royal prest for $£ 700$ to be spent on the King's works at Westminster. 


\section{0 / Renaissance and Reformation}

36 LP, XIII.ii.491 (11); XVII.881 (11); CPREd, 1, 139, 261; British Library, Harleian MS. 1419, fo. 119. Besides Westminster Denny was also keeper of the palace at St. John's near London. LP, XXI.ii.754.

37 LP, IX.229, 232; X.376; XI.516; XIII.ii.457.II(12); XVII.258 (fo. 50), 354, 526; XVIII.i.436 (fo. 76); XIX.i.388.3, 1035.27; XXI.ii.202 (2); HMC. Eighth Report. Part II(London, 1881), p. 21; Acts of the Privy Council of England 1542-1628, eds. John R. Dasentet al. (46 vols., London, 1890-1964), II, 78, 87, 146, 153 (hereafter $A P C$ ).

38 LP, XVII.267.

39 LP, VII.1012; XV.1029 (10); I.Addenda.ii.1567; see also X.254 for Cromwell's interest in examining the accounts of the clerks of the King's works.

$40 L P$, XIX.i.1035.27.

41 Ibid., (10). The account of subsidies, tunnage and poundage of the port of London from 29 September 1545 to 29 September 1546 during Denny's customership is to be found in Pipe Office Roll No. 764. List \& Index Society, List and Index of the Declared Accounts from the Pipe Office and the Audit Office (Rpt. New York, 1936), p. 24; CPREd, I, 269. From 18 February 1541 Denny was represented by a deputy at the port of London. $L P, \mathrm{XVI}$.678.27.

$42 L P$, XIV.ii.781 (fos. 58b, 59b): Denny's wage in the wardrobe was not paid for January and February 1539 . Henry was frequently short of ready cash and his officials often had to wait. Situations were worse for Mary's officials, whose payments were habitually in arrears. Robert C. Braddock, "The Rewards of Office Holding in Tudor England," The Journal of British Studies, XVI, 2 (1975), 38.

43 William H. Smyth, "Description of an Astrological Clock, belonging to the Society of Antiquaries of London," Archaeologia, 33 (1849), 16.

44 I owe this interesting comparison to an anonymous critic of an earlier version of this paper.

45 The Loseley Manuscripts, ed. Alfred J. Kempe (London, 1836), p. 3.

46 John Strype, Ecclesiastical Memorials, 3 vols. (Oxford, 1822), I.ii.459; LP, XV.825 (p. 395).

$47 L P$, XVIII.i.71, 725, 911.

$48 L P$, XIX.ii.334. Richardson wrongly states that Denny was knighted under Edward VI. Chamber Administration, p. 422 n. Denny's knighthood was certainly the outcome of Henry's desire to reward his servants on the occasion of his victory in battle. It probably was not, as two scholars seem to believe, a reward for Denny's martial exploits at Boulogne. Dale E. Hoak, The King's Council in the Reign of Edward VI (Cambridge, 1976), p. 86 n. 238; G.E. Mingay, The Gentry; the Rise and Fall of a Ruling Class (London, 1976), p. 9.

49 By a grant of 31 August 1546 this authorization was extended until 10 May 1547. These men had to be issued a "special pardon" from time to time in order to absolve them from charges of treason by counterfeiting the royal signature. Thomas Rymer, Foedera ( 10 vols. in 20 , third edn., London, 1739-45), VI.iii. \& iv.138-9; LP, XXI.i.1537 (32-4).

$50 L P$, XIX.i.293. Hertford was seeking the King's favour for a suit of David Clayton's. HMC. Seymour Papers, pp. 90-91: Berwick's letter to the Earl of Hertford, 6 March 1543; SP, II, 840: Wriothesley to Paget, 11 November 1546; IX, 694 (No. 971); LP, XX.ii.864.

51 APC, II, 16-20. Paget claimed, "as it is well known that he [Henry] used to open his pleasure to me alone in many things." He even boasted to the French ambassador that "not even Wolsey or Cromwell had the freedom of speech with Henry that he did during the King's last months." Samuel R. Gammon, "Master of Practices: a Life of William Lord Paget of Beaudesert 1506-63" (unpublished Ph.D. thesis, Princeton University, 1953), p. 188.

52 LP, I.Addenda.ii. 1794.

53 "Some Cautionary Notes on Henry VII's Household and Chamber System," Speculum, 33 (1958), 75.

54 "The Royal Household, 1540-1560" (unpublished Ph.D. thesis, Northwestern University, 1971), p. 212.

55 Fleta, ed. John Selden, 4 pts. (London, 1695), II, 16: this sentence refers to the position of a medieval camerarius. Wolsey's famous remark highlighting the importance of a privy chamber 
official is too well known to repeat here. George Cavendish, The Life and Death of Cardinal Wolsey, ed. Richard Sylvester (London, 1958), p. 157.

56 Edmund Lodge, Portraits of Illustrious Personages of Great Britain, 12 vols. (London, 1823), I: "Anthony Denny."

57 Acts and Monuments, V, 689; The Statutes of the Realm, eds. Alexander Luders et al, 11 vols. (London, 1963), II, 98: law against the soothsayers. In 1541 Walter Lord Hungerford was executed for foretelling the king's death.

58 Rymer, Foedera, VI.iii. \& iv.145; LP, XXI.ii.634.1. Denny's award was actually collected by his widow. $A P C$, II, 385 . In his will Denny recognized his master's princely bounty. Somerset House, 37 Populwel: "The Will of Sir Anthony Denny."

59 Strype, Ecclesiastical Memorials, II.ii.298-9.

60 Calendar of Letters, Despatches, and State Papers. Spain, eds. Gustav A. Bergenroth et al., 13 vols. (London, 1862-1954), IX, 21: report of Van der Delft.

61 CPREd, I, 243.

62 Ibid. pp. 83-4.

63 On 12 February 1548 Denny sat in the House of Commons to hear and determine the suit between Thomas Hubbard and Sir Nicholas Hare. Journals of the House of Commons 1547-1900, ed. Edgar L. Erickson, 155 vols. (London, 1803-1901), I, 8.

64 APC, II, 74, 78, 87, 146, 153, 188; HMC. Seventh Report. Parts I \& II (London, 1879), p. 605; Harold A. Dillon, "Arms and Armour at Westminster, the Tower, and Greenwich, 1547," Archaeologia, 51 (1888), 268.

65 This is the date of the patent. CPREd, II, 94. His actual commission from the privy council was dated 21 March 1547. APC, II, 70.

66 Hoak, Council of Edward VI, p. 304.

67 APC, II, 263.

68 J. Strype, The Life of the Learned John Cheke, Kt. (Oxford, 1820), p. 168: "flectere mentem Henrici potuit, miscens nunc dulci, seria nunc levibus texens, nunc grandia parvus" ("Carmen Heroicum").

69 Ellis, Original Letters, p. 14: Ascham's letter to William Cecil, 23 March 1553.

70 Baldesar Castiglione, The Book of the Courtier, tr. Charles S. Singleton (New York, 1959), p. 114.

71 Denny was a fairly wealthy man. His minimum income from land amounted to about $£ 700$. Robert E. Brook, "The Early Tudor Courtiers in Society, illustrated from Select Examples" (unpublished Ph.D. thesis, University of London, 1963), pp. 271-273.

72 David Lloyd, State-Worthies (London, 1670), p. 146.

73 Robert Beale, "A Treatise of the Office of a Councellor and Principall Secretarie to Her Ma/jes/ tie" (1592), printed in extenso in Conyers Read, Mr. Secretary Walshingham and the Policy of Queen Elizabeth, 3 vols. (Oxford, 1925), I, 443: "that he be neither troublesome to him [king] nor subject of other's envy" (English translation of the Latin clause in the quotation). Also see Ben Jonson, Eastward Hoe (1605), Sig. Cir . 